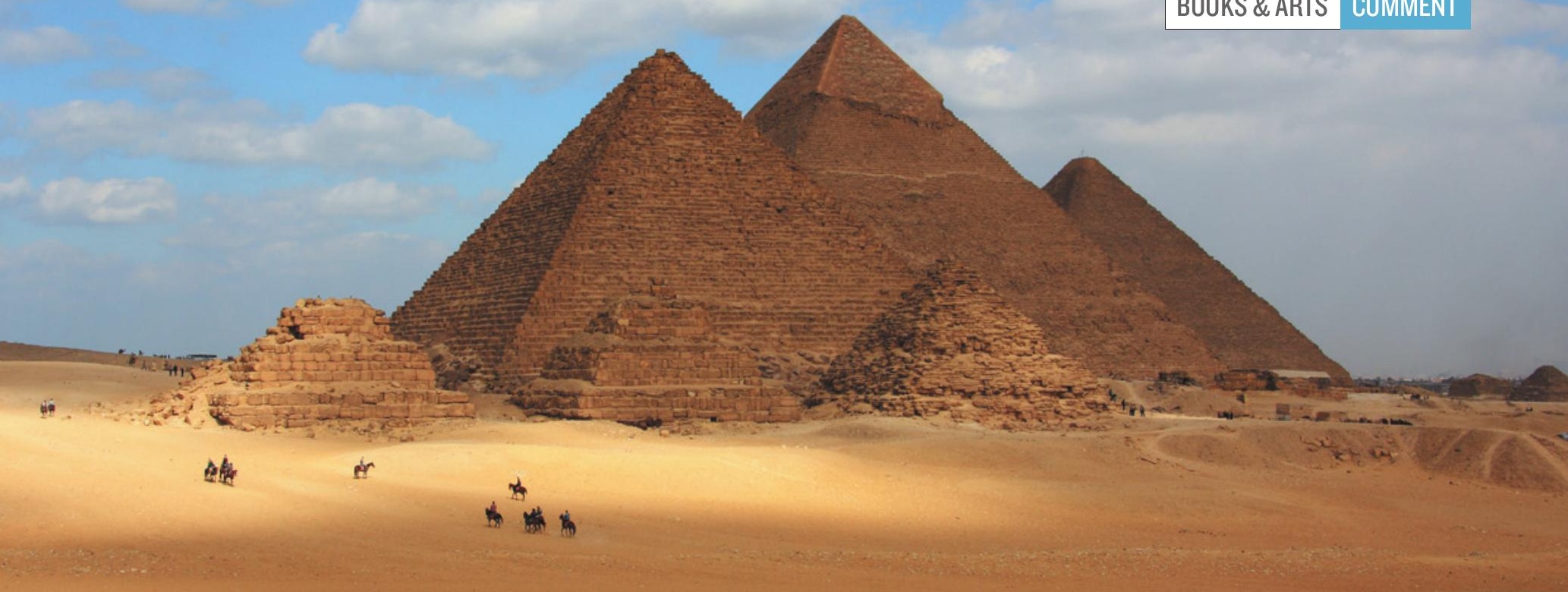

The pyramids at Giza — the culmination of two-and-a-half millennia of developing civilization — have tantalized archaeologists for centuries.

\title{
From ploughs to pyramids
}

\section{Andrew Robinson discovers gems in a grand overview of ancient Egypt and the life of a pioneer in Egyptology.}

$\mathrm{T}$ The Great Pyramid at Giza was once thought to be geometrically perfect - not least by Isaac Newton. It wasn't until 1798, when Napoleon Bonaparte's surveyors arrived in Egypt, that the pyramid was discovered to be flawed. Even so, the deviation from a perfect square in the four final baselines of this extraordinary edifice, constructed as a tomb for pharaoh Khufu (also known as Cheops) around $2550 \mathrm{BC}$, is less than 18 centimetres in 230 metres.

How this precision was achieved is now well understood. But mystery shrouds Khufu himself: all that Napoleon's scientists found in his burial chamber was an empty sarcophagus. It had been robbed in antiquity. As Egyptologist John Romer writes in A History of Ancient Egypt: From the First Farmers to the Great Pyramid, "Nothing of Khufu the man is known."

Despite many such historical blanks, Romer aims to provide a monumental survey of two and a half millennia, from Egypt's agricultural dawn in 5,000-4,000 BC to the reign of Khufu. This is the first volume of a projected two-volume study - the fruit of the author's archaeological activity in Egypt since the mid-1960s.

Romer's book is the most wide-ranging since British philologist Alan Gardiner published Egypt of the Pharaohs (Oxford Univ. Press, 1961), which itself replaced US archaeologist James Henry Breasted's A History of Egypt (Scribner, 1905). Breasted's study

A History of Ancient Egypt: From the First Farmers to the Great Pyramid JOHN ROMER

Allen Lane: 2012. 512 pp. £25

American Egyptologist: The Life of James Henry Breasted and the Creation of His Oriental Institute

JEFFREY ABT

University of Chicago Press: 2012. 536 pp. £29, \$45

was a popular hit that was also admired by Egyptologists, and it is fitting that he should at long last get his due in Jeffrey Abt's deeply researched biography, American Egyptologist.

Romer is fortunate in that a mass of important archaeological discoveries have been made in the past 50 years. In the 1980s, for instance, German archaeologists clearing a royal tomb at Abydos discovered the oldest group of inscribed artefacts so far known in Egypt, dating to about 3200 BC. They include nearly 200 bone and ivory tags, once probably attached to grave goods. At least some of the pictograms on the tags strongly resemble the first hieroglyphs, which date from the early third millennium BC.

Earlier finds also feature: Romer describes an underground tomb in the shadow of the Great Pyramid, discovered in 1925. Its owner,

\section{$\rightarrow$ NATURE.COM}

For more on modern Egyptology:

go.nature.com/eqwdoh
Hetepheres, was identified from damaged golden hieroglyphs originally mounted on strips of ebony on the back of a small royal palanquin. One of her titles was "mother of the King of Upper

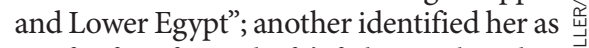
a wife of Sneferu, Khufu's father, making her $\vec{\Sigma}_{\text {. }}$ a candidate for the pyramid-builder's mother. Hetepheres's sarcophagus was as empty as her putative son's, but four packets of her entrails - some still steeping in natron - were discovered in an alabaster chest. As Romer says, it is "precisely this mixture of intimacy, anonymity and grandeur, at once alien and familiar" that makes Egyptology so fascinating.

However, the lack of data poses a challenge to historians of ancient Egypt. Romer breaks away from the approach of Breasted and Gardiner, who understandably tended to emphasize the knowledge derivable from Egyptian scripts and to downplay non-literate sources. Unlike Romer, they also concentrated on the ruling elite, and tended to look through the lens of their training in the history of ancient Greece, Rome and the Bible lands.

Breasted (1865-1935) has several claims to fame apart from his History. He was the first US citizen to gain a PhD in Egyptology. He assiduously documented hieroglyphic inscriptions using photographs, and played an important part in reading the inscriptions in the tomb of Tutankhamun. He founded the influential Oriental Institute at the University of Chicago in Illinois in 1931 . He coined the phrase 'fertile crescent' to refer to the area of the Middle East - chiefly Mesopotamia - in which some of the earliest $>$ 
human civilizations arose. And some have suggested that he was the model for the fictional archaeologist Indiana Jones, who studied at the University of Chicago. In 1931, Breasted's portrait featured on the cover of Time magazine.

Breasted's weakness as a historian was his religious motivation, as Abt clearly, if tactfully, reveals. Although hardly a Christian fundamentalist, Breasted saw Egypt as "an early example of mankind's potential but, as it had not been Christian ... bound to fail", according to a single dismissive sentence in Romer's book.

Romer's book is not without weaknesses of its own. His stated intent is "first, to provide a guide through the intellectual quagmire that modern 'ancient Egypt' has become, and also, by careful observation, to set some of the things the ancient people made back into their original realities." Although successful in his second aim, he is perhaps less so in his first.

It is not easy to enliven prehistory while simultaneously respecting limited archaeological evidence and avoiding novelistic pitfalls. But Romer manages it: his first chapter is a sparkling evocation of how, under the influence of the River Nile, Egypt's earliest inhabitants turned from hunter-gathering to farming around Lake Faiyum, in a depression in the Sahara. He shows how flint arrowheads found at Faiyum became less efficient, yet finer, over time, showing the growth of aesthetic feeling that would result in intricate weaving, elegant pots, beautiful paintings, expressive hieroglyphs and gigantic pyramids.

However, as a guide through the "intellectual quagmire", the book is sometimes tendentious in its anxiety to avoid conventional views on the enigmatic origin of the hieroglyphs. On aesthetic grounds, Romer assumes that the Egyptians borrowed from the writing system of Uruk in Mesopotamia (invented around $3300 \mathrm{BC}$ ), but this is not as obvious as he says: hieroglyphs could have been an indigenous invention. Moreover, the connection between the hieroglyphs and the simple pictograms found in Abydos is not clear: the pictograms do not all face to the right, like typical hieroglyphs.

But it would be churlish to suggest that Romer's project to shed light on an Egyptian era where historians fear to look is less than welcome. After a long wait, we have an up-to-date, stimulating account of the birth of what may turn out to be the world's oldest civilization.

Andrew Robinson is based in London and is the author of Cracking the Egyptian Code: The Revolutionary Life of Jean-François Champollion (Thames and Hudson, 2012).

e-mail: andrew.robinson33@virgin.net

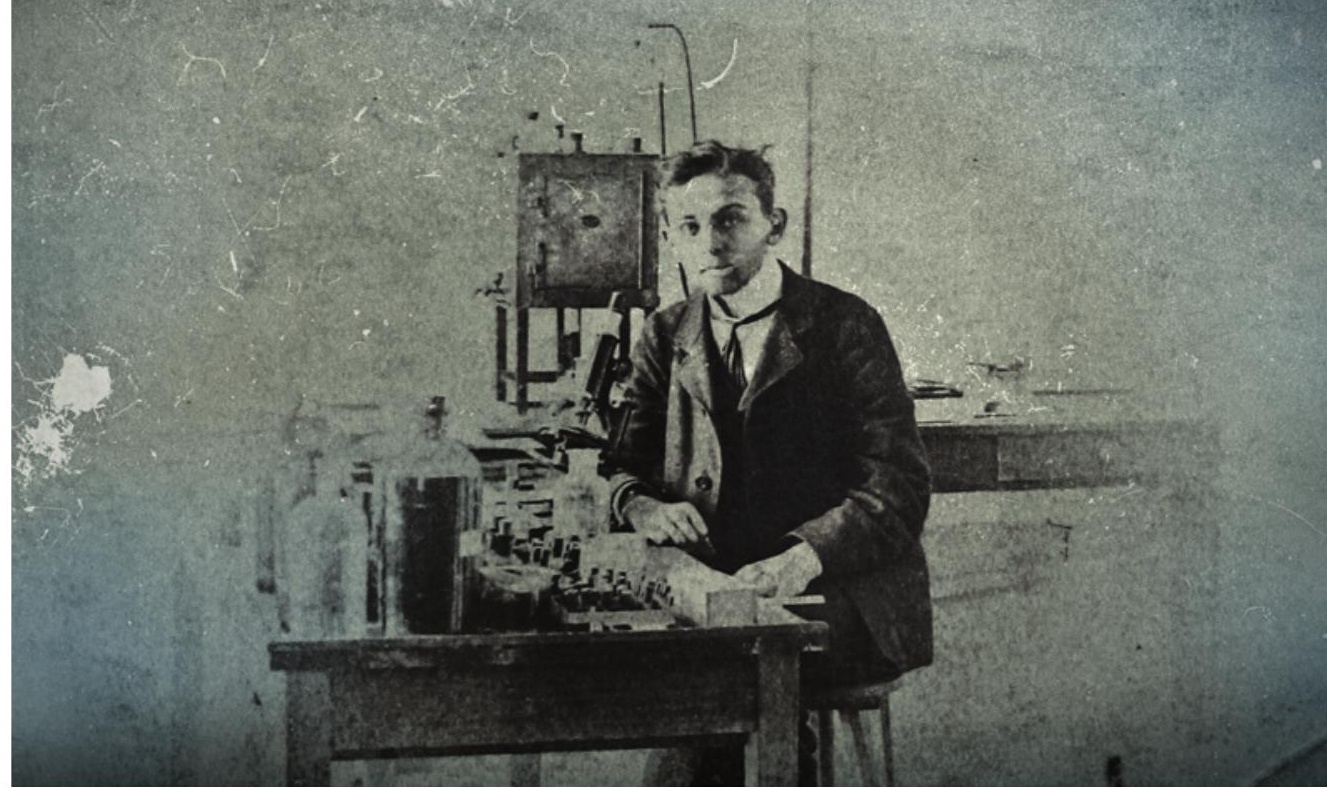

Sergej Tschachotin, pictured in 1907, used his ultraviolet scalpel to study sea-urchin parthenogenesis.

FILM

A radical in the lab

\section{Alison Abbott enjoys the story of a cell biologist whose incendiary life was shaped by revolution.}

A distracting weakness for women and politics meant that, unlike his friends Albert Einstein and Ivan Pavlov, the Russian microbiologist Sergej Stepanowitsch Tschachotin (1883-1973) never achieved scientific immortality. But in his time he was a renowned cancer researcher and innovative cell biologist - and his extraordinary life makes a riveting film.

Married five times and a frequent political exile, Sergej Tschachotin lived a life that reflected the tumult of twentieth-century Europe. So German film-maker Boris Hars-Tschachotin, one of Sergej's roughly 27 great-grandchildren, had a family story ripe for documentary.

Researching tales told by his grandfather Wenja Tschachotin, one of Sergej's eight sons, Boris made an unexpected discovery. Hidden in the Paris home of his greatuncle Eugen Tscha-

"Sergej in the Urin shows a man whose family life was incompatible with science and revolution."

chotin sat the urn containing Sergej's ashes, which had been collecting dust for 30 years. The film Sergej in the Urn, out this year in Germany, describes Boris's efforts to bring the family together to fulfil Sergej's last wish: to be buried in Corsica.

Irresolvable hostilities among Sergej’s four remaining sons halted that plan. But the documentary is all the more absorbing for that. It reconstructs the scientist's life and times from filial memories, archival footage of Nazi Germany and revolutionary Russia, and an unpublished autobiography that Eugen smuggled out Sergej in the Urn DIRECTED BY BORIS HARS-TSCHACHOTIN. Liquid Blues Production: 2009. DVD release August 2012. of the Soviet Union with the urn, letters and other documents.

Sergej's dual life as idealist-activist and scientist began early. As a student in Moscow, he was deported in 1902 for participating in protests against the Tsarist regime. He moved to Germany, where he continued his studies in Munich, Berlin and finally Heidelberg.

His first academic post was in Messina, Italy, where he was caught in the 1908 earthquake that killed more than 70,000 people. Miraculously, he and his first wife and son were pulled from the rubble alive, although Sergej's leg was crushed. In his autobiography he claims that during the subsequent surgery he thought up the 'ultraviolet scalpel' - a beam of ultraviolet light that can make precise cuts through biological tissue - for which he became moderately famous.

Back in Heidelberg, he made a prototype. He used it to manipulate individual cells under the microscope, which helped him to contribute to debates on subjects such as the response of cancer cells to treatments. He also used the scalpel to prod unfertilized seaurchin eggs into undergoing parthenogenesis.

On the strength of these successes, and to his enormous pride, Sergej was invited to join 